\title{
Black Work, Green Money: Remittances, Ritual, and Domestic Economies in Southern Kyrgyzstan
}

\author{
Madeleine Reeves
}

The road west out of Batken, the southern provincial town of 11,000 that in 1999 became Kyrgyzstan's newest regional (oblus) center, provides a vivid visual reminder of the complex new dependencies that connect livelihoods at the margins of Central Asia's newly independent states with the erstwhile Soviet center. ${ }^{1}$ Homes built from adobe bricks nestle alongside three-story houses with tiled roofs and satellite dishes jutting out over high walls. In the informal markets that straddle the largely unmarked Kyrgyzstan-Tajikistan border to the west of Batken, Russian rubles are used alongside Kyrgyz som and Tajik somoni: the currency of choice for returned labor migrants and their families, though technically illegal here. Kiosks and teahouses carry advertisements for buses departing for cities across Siberia and European Russia. And repainted mosques celebrate the names of villagers whose labor abroad has helped finance their reconstruction. Seasonal migration has become inscribed on the landscape of southern Kyrgyzstan in recent years, just as it has come, in more subtle ways, to reframe biographies, remake bodies, and transform apprehensions of wealth.

In the group of Batken border villages that I focus on in this article, the impact of remittances is as pronounced and complex as it is sudden. The generic expression, "gone to town" (shaarga ketken), is today used to refer to departures for Moscow rather than Batken, the region's administrative center, or Bishkek, Kyrgyzstan's capital. By the mid-2000s, the presence of "green money" ( $k o ̈ k ~ p u l)$ - a reference to the dollars that migrants remit home-meant that the new decade had come to be contrasted by villagers with the "hungry" 1990s, when expenditure on life-cycle ceremonies was dramatically curtailed and families resorted to killing livestock to sustain themselves through the winter. ${ }^{2}$ Many homes have been rebuilt

Research for this article has been variously supported by an Economic and Social Research Council doctoral training grant, a Research Councils UK postdoctoral research fellowship, a Nuffield Foundation small grant, and a travel fellowship from Newnham College, University of Cambridge. I am grateful to all of these organizations, and to the Universities of Cambridge and Manchester for supporting my research. An earlier version of this article was presented at a Social Science Research Council workshop, "Post-Collective Economic Lives and Livelihoods," in 2008, organized by Beth Mitchneck and John Pickles. I am grateful to the convenors and fellow workshop participants for their valuable feedback. The article has benefited from the opportunity to present working versions to seminars in Bishkek, London, Manchester, and Paris, as well as from the valuable feedback of the Slavic Review editor and reviewers.

1. Kyrgyz oblus is an equivalent administrative unit to the Russian oblast'. I alternate between Kyrgyz and Russian in the text according to the language in which the interview was conducted and/or the dominant terminology in my fieldsite. Names of all informants have been changed.

2. Kyrgyz kök can translate either "green" or "blue" according to context. Younger people in the village would often refer to dollars simply as "greens" (jashyl) without the

Slavic Review 71, no. 1 (Spring 2012) 
and the cost of bride-price (qalyng) has risen significantly since the new millennium. But if these changes have meant, as one elderly woman put it in 2005, that "people now say prayers to [Vladimir] Putin padysha [Tsar Putin] for creating the conditions for life [nan tapshyga shart kyldy]," they have also exposed just how conditional such labor is, and at what personal and social cost.

As in other global sites of transnational migration, decisions to send sons (and now, increasingly, daughters-in-law) to metropolitan Russia are made in the context of complex assessments about the relative costs of having family members leave or stay behind: decisions in which the opinion of the person migrating is not necessarily decisive. ${ }^{3}$ Such debates are freighted with economic and moral uncertainty: Will the family member who has departed be able to find work? Will she be able to secure a legal registration document? Will children who remain behind in the village become reserved from lack of social contact or excessively "free-willed" (erke) from the absence of parental discipline? Will a family member who has migrated earn enough for it to be considered a "successful" trip, but not so much that it might arouse envy and the spreading of hurtful gossip (ushaktar)? And will the person departing be able to avoid the ultimate risk of work that is typically unregulated and undocumented: a five-year deportation and the indignity of a night in detention?

These questions have been given new urgency by a global financial crisis that has stalled the oil-fueled construction boom of the Putin years. For while "the crisis" (krizis) has intensified the risks of sudden dismissal by employers and subcontractors unable or unwilling to pay salaries, it has not yet oriented domestic livelihood strategies in southern Kyrgyzstan away from seasonal labor in Russia (nor, from the villages discussed here, has it yet directed migration aspirations toward other possible global destinations). ${ }^{4}$ Indeed, if anything, it has simply raised the stakes of finding and keeping work, at whatever personal cost. ${ }^{5}$

qualifier "money. On the impact of economic crisis on social networks in Kyrgyzstan during the 1990s, see Kathleen Kuehnast and Nora Dudwick, Better a Hundred Friends than a Hundred Roubles? Social Networks in Transition-the Kyrgyz Republic (Washington, D.C., 2004), 15-22.

3. On the importance of incorporating the household into discussions of migration, see Douglas A. Massey, "Social Structure, Household Strategies and the Cumulative Causation of Migration," Population Index 56, no. 1 (Spring 1990): 3-26; Caroline B. Brettell, "Theorising Migration in Anthropology: The Social Construction of Networks, Identities, Communities and Globalscapes," in Caroline B. Brettell and James F. Hollifield, eds., International Migration: Talking across Disciplines (London, 2000), 97-136.

4. During my period of research, Russia was the exclusive destination for migrants from Ak-Tatyr and its neighbors, though Kazakhstan is an increasingly popular destination in other parts of Kyrgyzstan. In 2011, Jengish, one of my key informants, traveled to Dubai in the hope of obtaining work with a tourist visa. To my knowledge he was the first person from his village to do so. He returned after one month, however, departing soon thereafter for Moscow.

5. Interviews in 2008 and 2010 in Ak-Tatyr and neighboring Ak-Sai support the findings of official migration statistics from Kyrgyzstan, which indicate that the financial crisis did not lead to a significant reduction in the numbers of people leaving Kyrgyzstan in search of work in Russia. It did, however, have a dramatic impact on the rate of return 
This article explores these dilemmas and what they reveal about the domestication of new regimes of labor and new sources of wealth in rural Kyrgyzstan. Drawing on nineteen months' research in the Batken region between 2004 and 2010, I situate migration decisions within the context of domestic economies and public debate about the proper conduct of ritual obligations. In so doing, I question the tendency of recent literature on post-Soviet labor migration to explore motivations for migration in terms of rational individual responses to economic necessity. My critique is twofold. I draw attention, first, to the political economy of migrant labor: the way that specific structural conditions have served to undermine other sources of livelihood, including the role of new border controls in hindering local opportunities for trade. Macrolevel analyses of migrant "flows," important as these have been for understanding the potential of remittances to act as a tool of development, have tended to ignore the social embededness of economic decisions. The tendency to characterize Russia as "absorbing the surplus (especially male) labor from the Caucasus and Central Asian states," as one analyst recently argued, elides the fact that there are historical and political reasons why labor in these areas is in "surplus," just as there are political reasons why Central Asian labor in Russia is overwhelmingly unregulated, uncontracted, and therefore cheap. ${ }^{6}$

Second, I argue that while economic considerations are crucial for understanding the dynamics of labor migration from Central Asia, economic rationality alone does not exhaust the meanings of migration for either those who leave or those who stay behind. Remittances are being used to sustain a rich and elaborate ritual economy, which in turn is fostering new iterations of an enduring debate about the appropriate expenditure for marriages, circumcision ceremonies, and other life-cycle celebrations (toilar). While patterns of economic activity in southern Kyrgyzstan have altered dramatically in recent years, new forms of engagement in distant labor markets are also being used to sustain patterns of ritual gifting and expressions of ethnic and religious identity that are imagined and articulated precisely as demonstrations of social continuity. This has implications for understanding the diversity of ways in which new economic rationalities are appropriated and for developing a more nuanced account of the economic subject of postsocialist change, a theme that I elaborate below.

\section{Domesticating Departure}

The empirical material for this analysis consists of ethnographic interviews that I conducted with returned migrants and with the siblings, spouses,

migration, as those already in Russia decided to stay put in the hope of keeping or finding work, rather than returning home for the winter months. See also Irina Lukashova and Irina Makenbaeva, Vozdeistvie mirovogo ekonomicheskogo krizisa na trudovuiu migratsiiu iz Kyrgyzstana v Rossiiu: Kachestvennyi obzor i kolichestvennoe issledovanie (Bishkek, 2009).

6. Fiona Hill, "Eurasia on the Move: The Regional Implications of Mass Labor Migration from Central Asia to Russia” (Kennan Institute presentation, 24 September 2004), available at www.brookings.edu/views/op-ed/hillf/20040927.pdf (last accessed 1 December 2011). 
parents, and children of the many village men and smaller number of women who are engaged in seasonal work in Russia. I also draw upon a more structured household survey that I conducted in the summer of 2005 in four geographically contiguous villages in the Isfara Valley to the west of Batken. Once part of the same state farm and lying along the river valley that transects the Kyrgyzstan-Tajikistan boundary, three of the four villages are now subordinate to the same village administration (aiyl ökmötü), which takes its name from the largest of them, Ak-Tatyr. Connected through kinship and often spoken of as constituting a single social space, these villages today share a similar economic profile, with remittances the single largest source of domestic incomes. A total of 225 households were included in the survey, selected through a random sample of all village households. ${ }^{7}$ Although it in no way should be read as "representative" of migration from Kyrgyzstan as a whole-patterns of departure even between villages within a single district are distinct and localized-the survey nonetheless allows an insight into household migration strategies that are invisible within aggregate statistics on migrant "flows."

The period I explore here is important for understanding the transformation of labor migration abroad from exceptional to routine in rural Batken. By the mid-2000s, an oil-fueled construction boom had transformed Russia into the second net migrant-receiving country after the United States and made several post-Soviet economies among the most remittance-dependent in the world. ${ }^{8}$ Rural Batken, reeling from the impact of land privatization and new border controls, was no exception to this broader dynamic. By the mid-2000s a "season" of labor in Russiatypically between nine months and three years-was becoming a key source of domestic livelihood. It was also coming to represent a process of social "coming of age" for a significant proportion of young men, one that was often compared with service in the Soviet army for an older generation of males.

Such pressures were often attributed to the growing costs of marriage: friends and acquaintances would chart out the local increase in brideprice and lament that the Kyrgyz som had "lost its strength" (küchü jok bolup ketti) when it came to meeting this critical domestic expenditure. As

7. "Household," for the purpose of this research, refers to all those who live together bir qazan ("one cooking-pot") - that is, as a single economic unit, living around the same garden plot, sharing resources, and eating together. The average household size in the villages surveyed was 6.2 people ( 3.2 adults and 3.0 children); thus, the survey covered a total of 1,395 people - or just over a quarter of the total population of the four villages.

8. International Organization for Migration, World Migration 2005: Costs and Benefits of International Migration (Geneva, 2005); Ali Mansoor and Bryce Quillin, Migration and Remittances: Eastern Europe and the Former Soviet Union (New York, 2006); World Bank, Migration and Remitances Factbook 2011 (Washington, D.C., 2010). According to research conducted by Inter-American Dialogue, cited in the New York Times in 2007, Tajikistan derived 37 percent of its gross domestic product (GDP) from remittances in 2007, making it the third most remittance-dependent country in the world after Guinea-Bissau and Eritrea. The same data characterizes Kyrgyzstan as the seventh most remittance-dependent, deriving 28 percent of its GDP from remittances. Jason DeParle, "Migrant Money Flow: A \$300 Billion Current," New York Times Week in Review, 18 November 2007, WK3. 
in other parts of Central Asia, a season's work in town was also increasingly the index of a more general ability to provide for one's extended family and a marker as such of mature manhood. ${ }^{9}$ Photos sent back by young men to parents and wives emphasized the physical demands of labor and the technical mastery of new equipment. Money sent back to help fund another family member's education or physical repairs to a parent's home would serve as public markers of proxy presence and filial duty: a way of maintaining a social place in the village in the face of protracted physical absence.

Such dynamics point to the need for an expanded analysis of Central Asian labor migration: one that recognizes its embeddedness within local structures of value. It also prompts new questions about the investment of remittances and the social and symbolic import of ritual expenditure. Academic and policy-oriented studies of Central Asian labor migration have tended to focus on macroeconomic dynamics and the potential for remittances to act as drivers of development. ${ }^{10}$ Such empirical concerns are often coupled with exasperation at the seemingly "irrational" expenditure on life-cycle ceremonies that can accompany a migrant's return. A recent policy analysis, for instance, outlines the "moral hazards" that a remittance economy presents to governments and families alike. Governments "escape from the pressures for urgently needed structural reforms," while "most remittance-taking families experience moral hazard problems $[s i c]$, some entirely forgo productive activities, and tend to live lucrative and lazy lives." 11

Such concerns have prompted appeals by political and religious leaders in Central Asia for people to curtail their ritual expenditure, a contemporary instance of concern with "irrational" expenditure that has a long history in the region. ${ }^{12}$ In May 2007, prompted by fears that money remit-

9. Madeleine Reeves, "Migrations, masculinité et transformations de l'espace social dans la vallée de Sokh," in Marlene Laruelle, ed., Dynamiques migratoires et changements sociétaux en Asie Centrale (Paris, 2010), 131-47.

10. Samagan Aitymbetov, "Emigrant Remittances: Impact on Economic Development of Kyrgyzstan" (International Center for Economic Growth, European Centre, Working Paper 31, Budapest, 2006); Kursad Aslan, "Labor Migration and Its Potential Consequences for Central Asia," Central Asia-Caucasus Analyst, 16 April 2008, 13-15; Aziz Atamanov and Marrit Van den Berg, "Permanent, Seasonal Migration, Remittances and Other Income Sources in Source Communities: Evidence from the Rural Areas of the Kyrgyz Republic" (unpublished working paper, 24 June 2010), available at ssrn.com/ abstract=1629953 (last accessed 1 December 2011); Christine Bichsel, Silvia Hostettler, and Balz Strasser, “'Should I Buy a Cow or a TV?' Reflections on the Conceptual Framework of the NCCR North-South Based on a Comparative Study of International Labour Migration in Mexico, India and Kyrgyzstan" (Berne, 2005); Lukashova and Makenbaeva, Vozdeistvie; Erica Marat, "Labor Migration in Central Asia: Implications of the Global Economic Crisis" (Silk Road Papers Series, Washington, D.C., 2009); Saodat Olimova and Dzhamshed Kuddusov, Sem'i migrantov v Tadzhikistana: Problemy $i$ sposoby ikh resheniia (Dushanbe, 2007); Irene Röhner, National and International Labour Migration: A Case Study in the Province of Batken, Kyrgyzstan (Berne, 2007); Nurgul Ukeeva, "Migration, Remittances and Growth" (PhD diss., Duke University, 2010).

11. Aslan, "Labor Migration," 14.

12. Adeeb Khalid shows how the Jadids, reformist intellectuals in early twentiethcentury Central Asia, criticized excessive ritual expenditure as profligate and contrary to 
ted by Tajikistan's 600,000 migrant workers was being squandered on lavish celebrations, the lower house of the Tajik Parliament passed a law dramatically curtailing ritual expenditure (and signaling a new level of state intrusion into domestic affairs).$^{13}$ In Uzbekistan, President Islam Karimov in his December 2002 address to the nation publicly criticized "excessive expenditure" on weddings and funerals, "which parades as tradition."14 And in Kyrgyzstan, President Kurmanbek Bakiev chose to highlight the perils of excessive ritual expenditure just days before he was forced from office in a popular uprising. At the March 2010 Congress of Harmony (Yntymak kurultaiy) convened in an atmosphere tense with anger at rising utility prices, Bakiev located responsibility for the country's economic woes firmly in the private domain. "We should look soberly at certain of our observances [urp-adattarybyz] and traditions [yrym-jyrymdarybyz] and ask how appropriate and suitable they are in the realities of the twenty-first century, the epoch of globalization," Bakiev commented to the hall of carefully selected delegates. "I have in mind those observances and rituals that carry with them unjustified and sometimes even unthinkable expenses, when people fritter away their time and money, unthinkingly throwing to the wind what they have earned with their painstaking labor."15

The current crisis, the message seemed to be, is the fault, not of structural conditions, but of everyday profligacy, a fact that "is not just the concern of the president":

It is evident that it is time to radically change [lit. "cut"] our habitual perspective: we need to learn how to invest those resources that we currently spend on innumerable ritual gifts and meals on the education of our children and on the health and development of our families. And of course, we all should know that that considerable money that we currently waste on a mass of cheap and unnecessary clothes that we present to each other on such occasions is all an investment of money in the economy of another country! What is stopping us from changing this incorrect tradition, respected delegates? What do you say? ${ }^{16}$

"true" Islam; for Soviet rulers, such expenditure was criticized as contrary to the modest consumption expected of socialists. Adeeb Khalid, Islam after Communism (Berkeley, 2007), 120. On the more general transformation of Muslim ritual practice under communism, see Mark Saroyan, Minorities, Mullahs and Moderntity: Shaping Community in the Former Soviet Union (Berkeley, 1997), 64-65.

13. The law, "On the Regulation of Traditions, Celebrations and Rituals in the Republic of Tajikistan," stipulated the number of people who could be invited to a wedding ceremony (150 guests) or circumcision feast (60), as well as the amount of food that could be served and the number of cars that could be included in a wedding cortege (no more than four). Zakon Respubliki Tadzhikistan Ob uporiadochenii traditsii, torzhestv $i$ obriadov v Respublike Tadzhikistan ot 8 iiunia 2007 goda, no. 272, at agencynau.tj/zakoni/z.\%20u\%20t .html (last accessed 1 December 2011).

14. "I. Karimov: 'Pyshnye torzhestva i zastol'ia diskreditiruiut nashi national'nye tsennosti ... ' (vystuplenie)," Centrasia.ru, 9 December 2002, at www.centrasia.ru/newsA .php?st=1039412040 (last accessed 1 December 2011).

15. "Prezident K. Bakievdin Yntymak kurultaiyna kairyluusu," Azattyk unalgysy, 23 March 2010, at www.azattyk.org/content/Kyrgyzstan_Bakiev_Speach/1991474.html (last accessed 1 December 2011).

16. Ibid. 
Bakiev's rhetorical phrasing here implied that "cutting" ritual expenditure is a simple matter of will- or perhaps of presidential decree. As my informants often pointed out, however, cutting expenditures, or the relations they signal, is never quite so simple. And this is perhaps especially so in the context of protracted absence, when the conduct of rituals and the exchange of gifts becomes a crucial means for affirming social presence.

By situating migration decisions within complex family debates over proper accumulation, expenditure, and the observance of collective social obligations ( salt), I seek to offer a less normative reading of the motivations for migration and the tendency for remitted money to be invested in the ritual economy. The decision to send one or more family member to Russia in search of work is indeed often driven by economic necessity. But we cannot explain the shifting dynamics of migration within any given household or village, still less the social navigation of its impacts, without also locating a departure "for town" firmly within the realm of social obligations and ethical debate: that is, within broader concerns about the proper accumulation and distribution of wealth; about the production and maintenance of respectful relations, and about the meanings and consequences of family absence.

\section{Migration, Neoliberalism, Subjectivity}

Such concerns point, in turn, to the second aim. This is an intervention into a broader debate about how we might do descriptive and theoretical justice to the transformation of subjectivities and social practices that has accompanied incorporation as gastarbaitery (guest workers) into some of the most competitive and deregulated sectors of the Russian labor market. ${ }^{17}$ Beth Mitchneck and John Pickles, in a recent programmatic paper, ask what it means for subjects and collectivities "when a world turns, when the very fabric of institutions, practices and the norms that sustains them shifts from one register to another?"18

That shift, for rural Kyrgyz farmers and pastoralists incorporated at the sharp end of Russia's oil-fueled construction boom, has been acute. Uncontracted and precarious, the informal labor on commercial and individual building sites on which livelihoods in villages like Ak-Tatyr have come to depend is at the sharp edge of contemporary Russian capitalism. This is a labor regime dominated by "black work" (chernaia rabota in Russian; kara jumush in Kyrgyz): a term that gestures at once to its physical demands, its low social standing, and its ambiguous relationship to the formal economy. It is a labor regime, moreover, that is assertively "neoliberal," both in its formal characteristics-dependent upon the unfettered operation of markets, lack of wage protection, and the free movement

17. The term gastarbaiter, borrowed from the German, entered popular usage in Russia in the early 2000 s and is today widely used to refer to migrant laborers from the former Soviet Union.

18. Beth Mitchneck and John Pickles, "Inter-Asian Connections and Post-Collective Economic Lives: A Report on the SSRC Dubai Workshop, February 23-25 2008" (unpublished manuscript, 2008), 1. 
of labor power - and in its promotion of a particular rationality of governance in which productivity depends upon worker self-fashioning into calculative, reflexive, and "responsibilized" subjects. ${ }^{19}$

Such characteristics demand that we bring post-Soviet labor migration into broader conversation with analyses of human movement elsewhere: to develop, as Leyla Keough has argued in her insightful analysis of gendered migration from Moldova to Turkey, a "common global analytic" that enables us to see how "new moral economies" in sending communities "are affected by and coincide with global neoliberal processes and structures of oppression." ${ }^{20}$ And yet, developing a "common global analytic" is only half of the task. As scholars of postcollective livelihoods have shown in diverse settings, projects of neoliberal restructuring are rarely smooth or complete; nor do they occur in a vacuum, transforming passive subjects into monochrome neoliberal selves. ${ }^{21}$ Recognizing the role of neoliberal restructuring in shaping new patterns of movement, new concepts of work, and new articulations of "local" and "foreign" labor does not in itself tell us about how such logics play out in particular settings, or how they intersect with (and potentially either appropriate or are undermined by) quite different economic rationalities, structures of value, or concepts of the person. As Lisa Hoffman, Monica DeHart, and Stephen J. Collier have noted in an insightful recent critique, the generally implicit understanding of neoliberalism in much social scientific literature has tended to overshadow anything resembling a sociology of neoliberalism, attuned to the variety of ways in which political rationalities and technologies of calculative choice are applied and practically enacted in different settings. ${ }^{22}$ The analytic challenge, I suggest, is to couple a "global analytic"

19. My characterization of neoliberalism here draws upon the work of Andrew Barry, Thomas Osborne, and Nikolas Rose, who stress that neoliberalism designates more than a simple process of "rolling back the state." They describe it as a distinctive rationality of governance, which aims to "produce a degree of 'autonomization' of entities of government from the state" resulting in an "autonomization of society." Neoliberal interventions are exercises in governance but also of self-governance, by creating "chains of enrolment, 'responsibilization' and 'empowerment' to sectors and agencies distant from the centre, yet tied to it through a complex of alignments and translations." See Andrew Barry, Thomas Osborne, and Nikolas Rose, eds., Foucault and Political Reason: Liberalism, Neo-Liberalism and Rationalities of Governance (Chicago, 1996), 11-12.

20. Leyla J. Keough, “Globalizing 'Postsocialism': Mobile Mothers and Neoliberalism on the Margins of Europe," Anthropological Quarterly 79, no. 3 (Summer 2006): 434.

21. I borrow the term postcollective from Beth Mitchneck and John Pickles, who use it as a way of avoiding the overworked binaries of planned versus market, socialist versus postsocialist, or collective versus individualistic economy. They define postcollective economies as those that "share - to some extent-the experience of de-collectivization and political and economic liberalization, even as they may remain socialist and/or collective, as they reform, or as they (re)build socialist and collective institutions." John Pickles, "The Spirit of Post-Socialism: Common Spaces and the Production of Diversity," European Urban and Regional Studies 17, no. 2 (April 2010): 133.

22. Lisa Hoffman, Monica DeHart, and Stephen J. Collier, "Notes on the Anthropology of Neoliberalism," Anthropology News 47, no. 6 (September 2006): 9-10. See also Lisa Rofel, Desiring China: Experiments in Neoliberalism, Sexuality and Public Culture (Durham, 2007); John Clarke, "Living with/in and without Neoliberalism," Focaal- European Journal of Anthropology 51 (Summer 2008): 135-47. 
with ethnographic attention to the specificity of particular experiences: what Caroline Humphrey a decade ago called that "great range of cultural ways of being and doing in the post-Soviet world." 23

I extend this critique here by pointing to the ability of returned labor migrants to move between different (and seemingly contradictory) economic rationalities at different times and in different relational configurations. My respondents often commented on the way in which logics of reward and punishment transformed their behavior, dress, attitude to time, comportment, language, and habitus in metropolitan Russia. At the same time, however, widespread out-migration has also served to reinforce domestic hierarchies and reinvigorate practices of gifting that are identified by participants as both paradigmatically traditional and as expressly opposed to an instrumental logic of calculation. Indeed, in the realm of ritual economy that I focus on here, the emergence of new extremes of wealth and the pervasiveness of protracted absence "in town" has, if anything, increased the importance of sustaining salt - those domains of customary obligations of participation, reciprocity, and deference that organize social relations and sustain membership-in-absentia. ${ }^{24}$ Migration, in other words, may be qualitatively "new," but it is often spoken of by migrants and their families as precisely that which, in the current crisis, enables the continuation of an authentically Kyrgyz hospitality.

\section{Going to Town: The Scale and Scope of Labor Migration from Ak-Tatyr}

Ak-Tatyr and its neighbors are located along a thin fertile strip of land on either side of the Isfara River, at the southern edge of Central Asia's Ferghana basin. Kyrgyz and Tajik populations have long derived a living from this river valley and the pastures that rise on either side. It is a landscape that is today crossed by an international border between Kyrgyzstan and Tajikistan: a border still awaiting definitive delimitation and a source of considerable local contention as pastures, canals, roads, bridges, and irrigation water have been transformed from shared resources into national property. ${ }^{25}$ The Isfara Valley is one of the most densely populated regions of Central Asia, has little industry, and is characterized by a severe shortage of irrigated land. In the summer of 2008, most homes in Ak-Tatyr received water for their domestic garden plots for just half an hour each fortnight, and many families had abandoned sowing the land that they had been allocated during privatization (ülüsh) because of its distance from

23. Caroline Humphrey, The Unmaking of Soviet Life: Everyday Economies after Socialism (Ithaca, 2002), xx.

24. On the importance of salt in organizing social relationships in Kyrgyzstan, see Judith Beyer, "According to Salt: An Ethnography of Customary Law in Talas, Kyrgyzstan" (PhD diss., Martin Luther University, Halle-Wittenberg, Germany, 2009).

25. On the politicization of these resources in the Isfara Valley, see Christine Bichsel, Conflict Transformation in Central Asia: Irrigation Disputes in the Ferghana Valley (London, 2009), 113-23; Madeleine Reeves, “Materialising State Space: 'Creeping Migration' and Territorial Integrity in Southern Kyrgyzstan,” Europe-Asia Studies 61, no. 7 (2009): 1277-1313. 
the village and the costs involved in its cultivation. In 2005, 74.6 percent of the adults of working age included in the household survey responded that they had no paid employment locally at all at the time of research; 7.3 percent had ad hoc or temporary work, and 17.9 percent had full-time work, primarily in the school, the village administration, or as taxi drivers between Ak-Tatyr and the regional center, Batken, 50 kilometers away. At the time of the survey ( July 2005), 14.6 percent of all adults from Ak-Tatyr were in Russia, and 58.7 percent of all households had sent at least one family member to Russia in the previous five years in search of work.

To understand the recent shift toward labor migration as a source of livelihood within this context of economic shortage, we must attend to questions of political economy. In the years "before Russia" (rossiiaga cheiin) as the 1990s are now spoken of, apricots and rice constituted the main source of cash, and apricot blossoms continue to coat this otherwise inhospitable "stony land" (tashtak jer) every March. The cultivation of rice and apricots on the state farms and domestic plots meant that this area of southern Kyrgyzstan had been a site of considerable seasonal travel to Russia as early as the 1970s, particularly to the kolkhoz markets of Nizhnii Novgorod. Schoolteachers used to make the journey during their summer holidays, and the income they derived provided a significant boost to sovkhoz earnings. Indeed, the town is still referred to affectionately by its Soviet name, Gorkii, by many in Ak-Tatyr today, including many people who have never traveled there themselves. ${ }^{26}$

Seasonal trade with Nizhnii Novgorod outlasted the Soviet collapse. The economic devastation of the early 1990s, however, combined with increasing obstacles to local cross-border trade, have made harvesting and selling apricots increasingly difficult. Apricots are a notoriously unpredictable crop: a sudden frost in early spring when the tree is in blossom can make the difference between an abundant season and none at all. And although in the 1990s it was sufficiently profitable to trade apricots in Russia one lorry-load at a time, customs dues and a road police in Kazakhstan with a voracious appetite for "fines" mean that now only the wealthiest of farmers have the capital to be able to sell their crop anywhere beyond the nearby border markets. As a rule, it is traders from neighboring villages of Tajikistan, with access to the rail network just across the border and sufficient capital to send a train-load of the crop at a time who are able to profit from today's competitive trade in dried fruit. ${ }^{27}$

Survey data reveal this shift away from market trade toward (primar-

26. In their research on Arslanbob in Jalalabat oblast', Matthias Schmidt and Lira Sagynbekova similarly found that the 60 percent of migrants from this village left for the single city of Sverdlovsk, with the trigger generally being a marriage between an Uzbek man and a Russian woman from Sverdlovsk following the man's military service there in the 1960s. Matthias Schmidt and Lira Sagynbekova, "Migration Past and Present: Changing Patterns in Kyrgyzstan," Central Asian Survey 27, no. 2 (June 2008): 119.

27. Sending apricots by train is more lucrative than by lorry in part because of the greater volume that can be transported, but also because it is easier to conceal the difference between real and declared volume when passing through customs points at borders. See Madeleine Reeves, "Border Work: An Ethnography of the State at Its Limits in the Ferghana Valley” (PhD diss., University of Cambridge, 2008), 80-82. 
Table 1

Sphere of Occupation of Returned Labor Migrants from Ak-Tatyr and Neighboring Villages during Their Most Recent Period of Employment in Russia, July 2005 (in percent, $n=132$ )

\begin{tabular}{lr}
\hline Private (individual) building site & 33.6 \\
Commercial construction company & 19.5 \\
State-owned construction company & 14.8 \\
Construction total & 67.9 \\
Market: sale/wholesale of dried fruits & 13.3 \\
Market: sale/wholesale of fresh fruits & 0 \\
Market: selling other goods & 0.8 \\
Shop: retail & 2.3 \\
Trade total & 16.4 \\
Catering & 5.5 \\
Service industry (including cleaning, nontrade market work) & 5.5 \\
Transport & 0.8 \\
Industry & 0.8 \\
Agriculture & 1.6 \\
Other & 1.6 \\
$\quad$ Miscellaneous total & 15.8
\end{tabular}

ily unskilled) construction work (see table 1). Whereas the majority of those respondents who had first traveled to Russia prior to 1991 were still involved, directly or indirectly, in trade (often, now, in wholesale or transportation), the vast majority of younger respondents were engaged in construction, a finding consistent with surveys of labor migrants in other parts of Batken. ${ }^{28}$ The move from trade to construction work was just one of several shifts widely noted in conversation and interviews. The increase in the proportion of recent school-leavers and school-aged children was also frequently commented upon, as was the move toward unskilled work as proportionately more of those leaving lacked professional trades and departed with little or no knowledge of Russian. ${ }^{29}$

28. Compare Röhner, National and International Labor Migration, 114-16. In her research from the village of Sai, also in Batken district, Bichsel found that "men almost exclusively work on construction sites." Bichsel, Hostettler, and Strasser, "Should I Buy a Cow or a TV?" 18. This shift toward construction accelerated with the passing of legislation in Russia in 2007 restricting the presence of foreign citizens in market trade. Delia Rahmonov-Schwarz, "Destination Russia: Migration Policy Reform and Reality," OSCE Yearbook 2006 (Hamburg, 2006), 289-99; Vladimir Mukomel, "Immigration and Russian Migration Policy: Debating the Future," Russian Analytical Digest, no. 7 (3 October 2006): 2-8; Anne Le Huérou and Amandine Regamay, "Nécessaires et indésirables ? Les migrants en Russie," La Revue Nouvelle, August 2007, at www.revuenouvelle.be/rvn_abstract .php3?id_article=659 (last accessed 1 December 2011).

29. In rural parts of Batken, most school-leavers today understand some Russian but have difficulty sustaining a conversation in the language. There is a marked generational (and gender) difference in this respect, with many middle-aged men acquiring fluency in Russian during military service in the Soviet army. On Russian becoming a "foreign language" in the Batken region, see Madeleine Reeves, "Schooling in Ak-Tatyr: A Shifting 
Since the mid-2000s there has been a gradual shift away from the migration of single, typically unmarried men, toward so-called family migration (üi-bölölük migratsiia), in which husband and wife travel together, occasionally accompanied by children and sometimes by the children's grandparents to provide practical and material support. Although the proportion of women migrating from Ak-Tatyr has increased in recent years, migration is still predominantly a male affair. In the 2005 survey, just 14.8 percent of all the individual recorded journeys over the previous five years had been made by women, most of whom were married. By 2008, there were isolated instances of single, unmarried women departing for work, often sharing accommodation with older female relatives, cleaning schools and offices. This particular development was fraught with domestic anxiety, however, as parents weighed the potential benefits of an unmarried daughter's income against the concern that if she became "too urban" (shaardyk bolup kalsa) she would be unlikely to be sought out in marriage upon return to the village.

The scale and scope of this recent migration from Ak-Tatyr often invited comparison among village elders with the wartime departure of men "to the front." It also invited frequent and angry commentary on the scale of economic dislocation that had turned precarious work in Russia into seemingly the sole viable source of livelihood. "Do you think I would leave my [3-year-old] son here if I had the choice?" one young father asked rhetorically in response to a question about his work on a Turkish building site, before slipping into a commentary about the officials (kattalar, lit. "big ones") who had dismantled Kyrgyzstan's own hopes of urban regeneration. And indeed, evidence for the broadly economic determinants of migration from the village is not hard to find. Asked to indicate up to three reasons from a pregiven list why they or members of their household had left for Russia in search of work, an absolute majority of migrant families surveyed indicated primarily "economic" motivations-with the lack of work locally and the need to cover everyday living costs ranking near the top of the list (table 2). The broadly economic determinants of migration are also reflected in responses to questions concerning the contribution that remittances make to domestic budgets. ${ }^{30}$

According to the 2005 survey, labor migrants who had returned to Ak-Tatyr during the previous year received an average monthly pay of 8,018 Russian rubles (\$285.66) and over the course of a year were able either to send or bring home an average of 37,195 rubles (equivalent to

Moral Economy," in Alan DeYoung, Madeleine Reeves, and Galina Vlyayeva, eds., Surviving the Transition? Case Studies of Schools and Schooling in the Kyrgyz Republic since Independence (Greenwich, Conn., 2006), 188-93.

30. Determining the real volume of money remitted and circulating in the village is, of course, an inexact science. Just as the migration of family members reflects collective decisions, so the investment of remittances is rarely an individual decision. The earnings of several extended family members are likely to be pooled by a household head, and those who are able to send money from Russia by post, bank, or through acquaintances may have little control over how or on what the money they send is spent. 
Table 2

Main Reasons Given for Leaving for Russia

in Search of Work (in percent, $n=132$ )

$\begin{array}{lr}\text { Because there is no work here } & 77.3 \\ \text { To cover the costs of everyday expenses (food, clothing, schooling) } & 64.4 \\ \text { To cover the costs of a single large expense (e.g., to cover the costs of a toi) } & 54.5 \\ \text { Because my relative(s) invited me } & 18.2 \\ \text { To see another country } & 12.1 \\ \text { To improve my knowledge of Russian } & 3.8 \\ \text { To improve my professional skills } & 3.0 \\ \text { To escape from domestic problems } & 1.5\end{array}$

Note: Will not total 100 percent because respondents could provide up to three possible reasons.

$\$ 1,322$ at 2005 rates). ${ }^{31}$ The sums of money both remitted and brought back in person varied widely (from nothing, in several cases where the migrant had been cheated and/or deported before the completion of a job, to 110,000 rubles $[\$ 3,919]$ over the course of a year by one successful brigade leader). ${ }^{32}$ More striking still is the place that remittances held in domestic budgets of migrant households. A significant minority of respondents identified remittances as a supplement to other sources of income, typically from land, livestock, and the sale of dried fruit, but an absolute majority of respondents indicated that remittances played a central role in the family budget, with a quarter describing the remitted cash as their sole source of household income (table 3).

It is unsurprising in this context that among non-migrating households, over a third of those surveyed indicated that they would willingly send one or other household member to Russia in search of work if only they had the resources to do so. ${ }^{33}$ Traveling to Russia from southern Kyrgyzstan involves considerable outlays on transport to Bishkek and beyond

31. This figure is the mean of all of the responses for migrant households; the median and mode are significantly lower. The mean is skewed by the fact that a small number of people were able to remit large sums of money. Approximately one-third of all respondents were able to send and bring back less than 20,000 rubles $(\$ 713)$.

32. Although a majority of respondents indicated that the migrant(s) in their household had been able to send money home in their absence (71.2 percent who were able, versus 28.8 percent who were not), banks and money-transfer firms such as Western Union were, in 2004-5, still regarded with some degree of suspicion, and "private," informal transfers of money through friends and acquaintances tended to be more common. This has changed significantly in subsequent years, with multiple banks opening in Batken.

33. In Ak-Tatyr, a significant minority of nonmigrant households were also unable to send family members to Russia because of an absence of appropriate travel documents. It is characteristic of border regions of southern Kyrgyzstan that many village residents (particularly women) are not in possession of valid Kyrgyzstani passports: this is particularly true of those women who moved or married into the village from Tajikistan during the 1990s and who are now unable to deregister from Tajikistani citizenship. "Kyrgyz Republic: Powerful Neighbours Imperil Protection and Create Statelessness," Refugees International Bulletin, 20 December 2007, at www.refugeesinternational.org/sites/default / files / kyrgyzstan 122007.pdf (last accessed 1 December 2011). 
Table 3

Earnings from Russia within Household Income (in percent, $n=132$ )

Earnings from Russia are our sole source of income $\quad 24.2$

Earnings from Russia represent one of our primary sources of income $\quad 31.1$

Earnings from Russia provide an addition to a different primary $\quad 39.4$

source of income

Earnings from Russia are not a significant source of income for our family $\quad 1.5$

\begin{tabular}{ll} 
No answer & 3.8 \\
\hline
\end{tabular}

(around \$200 in 2005), as well as expenses associated with obtaining winter work clothes, securing a temporary residence registration, and meeting the significant costs of living in urban Russia. Moreover, labor in Russia is itself fraught with risks - of nonpayment or underpayment for work undertaken; of being dismissed arbitrarily before completion of a job (a risk referred to colloquially as being "thrown" [kidalaga tüsh boluptur]), or being deported for having a "fake" (fal'shivye) or expired registration document. The possibility of traveling abroad in search of work thus demands a certain degree of financial security and, as in other sites of significant rural out-migration, the very poorest tend not to leave the village. ${ }^{34}$

\section{Beyond Migrant "Flows": Locating Migration Decisions within Domestic Economies}

Migration from Ak-Tatyr is, then, in the broadest sense, economically driven. This is hardly a surprising finding, and it is one which, implicitly or explicitly, animates much of the policy-oriented literature on migration management and remittance investment in Central Asia. ${ }^{35}$ But such an assertion is only the beginning of an explanation, not its end point. Migration has "become a fashion" (moda bolup kaldy), as one Ak-Tatyr schoolteacher put it in the autumn of 2004, commenting on the destination of recent school-leavers, for reasons that exceed economic necessity alone. Indeed, in interviews with returned migrants it is clear that migration itself is changing the nature of what constitutes economic "need," just as it is transforming conceptions of appropriate expenditures on bride-price, wedding parties, circumcision feasts (sünnöt toilar), and other life-cycle ceremonies that structure social and ritual life.

34. Priya Deshingkar and Daniel Start, "Seasonal Migration for Livelihoods in India: Coping, Accumulation and Exclusion" (Overseas Development Institute, Working Paper no. 11, 2003), 13; Arkan de Haan, "Livelihoods and Poverty: The Role of Migration-A Critical Review of the Migration Literature," Journal of Development Studies 36, no. 2 (December 1999): 1-47; Uma Kathari, "Migration and Chronic Poverty" (Institute for Development, Policy and Management, University of Manchester, Working Paper no. 16, March 2002).

35. Economic Policy Institute "Bishkek Consensus," Assessment of Workers' Remittances (Bishkek, 2005); Larissa Jones, Richard Black, and Ronald Skeldon, "Migration and Poverty Reduction in Tajikistan" (Development Research Center on Migration, Globalisation and Poverty, Working Paper C11, 2007). 
In unpacking "economic necessity," therefore, we need to locate domestic calculations within local structures of value and to ask how these are being affected by recent processes of change. Survey and interview responses suggest that three particular factors - the emergence of sharp economic differentials between earning potential at home and abroad; the role of social networks in making work available; and the perceived "inflation" in ritual expenses - are increasingly turning a period of migration abroad into part of a young Batken person's "coming of age." I consider each of these in turn.

\section{Emergent Differentials: The Costs of Staying Behind}

As my informants were well aware, differentials in earning power within the former Soviet space have grown exponentially in recent years. By the time of my research, the impact of migrant remittances upon local patterns of consumption was too stark not to be influencing domestic calculations, even among those who had determined "never to leave Batken." In the summer of 2005, a mathematics teacher from Ak-Tatyr school in the highest category, with 25 years' teaching experience and a double teaching load would still be earning 5-6 times less than he would as an unskilled laborer on a Moscow building site. ${ }^{36}$ This disparity was having devastating consequences for local schools, as it was widely acknowledged to be the educated, "confident" young men with decent Russian-language skills who were likely to fare best in urban Russia. It was also leading young people to question the benefits of a university education - historically a highly prized route for forging a life outside the village. ${ }^{37}$ For many current and aspiring students, the presence of a group of young recent school-leavers sporting the clothes, accessories, haircuts, and mobile telephones bought with productive "green money" earned in Russia was felt to be reversing the proper, normative relationship between study and earning potential. In the summer of 2005, as we took the bus together from Batken to his home in Ak-Sai, a few miles beyond Ak-Tatyr, Jengish, then a student in his third year of university in Batken, joked about his predicament as one of only a handful of schoolmates who had decided to persevere with his studies instead of leaving for Moscow: "What does the student who used to get 'twos' [i.e., failing grades] now have? A car and an apartment. What does the student who used to get 'threes' [poor grades] now have? A car, an apartment, and a dacha! And what does the student who used to get 'fives' [otlichnik-i.e., excellent grades] now have? Debts, fines, fears, illness, and hopelessness." Jengish recounted this in jest, of course, and with

36. An unskilled laborer from Ak-Tatyr working on a building site in Moscow in the summer of 2005 could hope to earn around 9,000 rubles (about $\$ 320$ at the time). With a double teaching load, a teacher in the "highest category" was earning $\$ 56$ at the same time. On the economics of schoolteaching in rural Batken, see Reeves, "Schooling in AkTatyr," $184-87$.

37. On the value and status attached to a university education in Kyrgyzstan, see Alan J. De Young, Lost in Transition: Redefining Students and Universities in the Contemporary Kyrgyz Republic (Greenwich, Conn., 2011). 
more than a hint of pride that he was, despite his precarious financial predicament, still the student who got excellent grades. A year later, however, the differential with his school friends who had returned with money to build homes and hold weddings had become, as he put it, a source of "embarrassment" (uiat), and Jengish, too, left for Moscow, temporarily abandoning his studies. In the summer of 2006, when I traveled from Bishkek to Moscow by train, I experienced his bittersweet life "in town" firsthand: Jengish met me at the Kazan' station, on his way to a 12-hour shift cleaning and stacking supermarket trolleys. As we rode the Moscow metro together, trading news about friends in Batken, Jengish's comments swung between the exhilaration and despair that he felt by turns in Moscow. He was managing to save money and was navigating his way in Russiana language that he had previously understood but barely spoken. But walking the streets near his home, he always felt like a "rabbit in a car's headlights" running to stay unchecked by the Moscow militia, unsure which way to leap. "Even if you don't get physically exhausted in Moscow, you will be morally exhausted [moral'no charchasyng]. Guaranteed."

\section{Social Networks and the "Snowball Effect"}

Jengish's case provides a striking illustration of the broader issues at stake in exploring the economics of migration from southern Kyrgyzstan. His departure for Russia was, in the most general sense, economically motivated. After the collapse of collectivized agriculture, his family derived a precarious existence from their 6 sotok (0.06 hectare) domestic plot and the small income they gained from leasing their 12 sotok of agricultural land to wealthier relatives. ${ }^{38}$ Jengish himself had worked in Batken's small commercial radio station to support the costs of attending university, but his earnings there represented just a small proportion of his annual fees. Above all, he wanted to help his older brother meet the considerable costs of holding a wedding feast after marrying in 2004.

There was, then, a material motivation for Jengish's eventual departure for Russia a year later: his family was relatively poor, and Russia offered far greater opportunities for well-paid work than Batken or even Bishkek. But material need alone gives us little insight into when and why Jengish decided to postpone his university studies; or how, within the space of just four years, the individual, seasonal, departure of a "pioneer" older brother had given way to the much longer-term migration of seven family members across three generations. For this we need to situate migration within local structures of value. Jengish chose this city as his destination because his older brother, and later, his sister-in-law, were already there and could help him secure work. He traveled together with his mother, his sister, and his sister's husband. And he could afford to live

38. Jengish's family had, like most in their village, been allocated two kinds of agricultural land: irrigated (suuluu) and dry (kairak). On the former they had previously grown rice; on the latter, wheat. The relatives who leased the land would pay Jengish's family back in rice (half of their harvest). By 2010, these relatives had also ceased cultivating rice, however, departing instead for Russia. 
on a salary that was just half of that earned by his colleagues with Russian citizenship because his extended family could provide him with accommodation once he arrived in Moscow.

Seven of Jengish's relatives lived together, along with another extended family, in a two-room flat in the far south of the city; his 50-year old mother played a crucial role in cooking, childcare, and "maintaining harmony," as Jengish put it, among the apartment's multiple tenants. Jengish's decision to leave, then, needs to be understood in the context of the broader domestic economy, one in which the number and age of siblings, as well as their respective position within a sibling hierarchy, play a crucial role. At a certain point, as for many other households involved in labor-intensive small-scale farming, the costs of remaining to tend the family fields were outweighed by the opportunities presented by having several family members working and living together "in town."

Such patterns of migration "snowballing" are reflected in the household survey data from Ak-Tatyr. A significant majority (72 percent) of those who had worked in Russia depended on siblings, friends and/or fellow-villagers to find their most recent job, while just 2.3 percent relied on a published advertisement or applied for their most recent employment through an agency (table 4$)$. A substantial minority (9.8 percent) found their job through an intermediary (ortomchu or posrednik [Russ.])typically, someone from Kyrgyzstan who had developed good contacts with local employers and who was well acquainted with the local mechanisms for hiring labor. Moreover, almost half (47.7 percent) of the returned migrants surveyed had been able to find work for friends, relatives, and schoolmates; in one case, a brigade leader had been able to secure jobs for 50 fellow villagers. Such findings help us to account for the otherwise striking speed at which migrants reported finding work, with over threequarters securing employment with a week of arriving in Russia. The importance of social networks of kin and friends also help to account for the intense degree of localization of migrant destinations. From Ak-Tatyr and neighboring villages, 67.9 percent of all journeys that had been made in the previous five years to Russia had been to the single city of Moscow, with a further 19.8 percent of journeys destined for Nizhnii Novgorod. Of the remaining migrant journeys, the only significant other destinations were St. Petersburg, Samara, and the Moscow region. ${ }^{39}$

\section{The "Inflation" in Ritual Expenses}

There is a further respect in which the case of Jengish's family is instructive in thinking about the economics of migration from southern Kyrgyzstan. This concerns the importance of remittances in sustaining ritual

39. The degree of localization of these destinations is vividly illustrated if we compare the survey data from the neighboring river valley of Sokh, where I conducted an identical survey in February and March 2005, with 282 household heads. From the Sokh Valley, not a single journey captured in the survey was to Moscow (a city widely regarded in Sokh as an excessively dangerous destination); the most popular destinations were Irkutsk, Novosibirsk, Barnaul, and Tomsk — cities not mentioned once by interviewees in Ak-Tatyr. 
Table 4

Means of Locating Most Recent Position in Russia

(in percent, $n=132$ )

\begin{tabular}{lr}
\hline I had worked for this employer before & 2.3 \\
Relatives invited me & 44.7 \\
Friends/fellow villagers invited me & 27.3 \\
Through an intermediary & 9.8 \\
Through an advertisement & 1.5 \\
Through an agency & 0.8 \\
Through contacts made in Russia & 5.3 \\
The employer approached me directly & 2.3 \\
Other & 3.0 \\
No answer & 3.0 \\
\hline
\end{tabular}

expenses - and, increasingly for young men, the importance of a period of work "in town" in proving oneself eligible for marriage. In Ak-Tatyr, as elsewhere in Kyrgyzstan, differences in fortune are calibrated materially, through physical repairs to homes and outhouses, or electrical goods, such as fridges, DVD players, and music centers, prominently displayed and decorated. But it is in life-cycle ceremonies that a significant proportion of income earned "in town" is invested and wealth most visibly performed.

As in other parts of Central Asia, weddings, anniversaries, and rituals to mark the birth of a child (beshek toi) or the circumcision of an infant son (sünnöt toi) are expensive affairs in the Batken region, often sealed through three days of feasting, with the exchange of goods, the slaughter of animals, and the payment of bride-price amounting in 2005 to over 40,000 som $(\$ 1,000) .{ }^{40}$ In Ak-Tatyr and its neighbors, the outlays on a toi are often indexed through comparison with the cost of livestock or large, single-item purchases. Responding to my question about the expenses that had been involved in marrying off her daughter, 50-year old Arapateje responded simply, "bir mashinanyn pulu ketti" (one car's-worth went to it). A wedding, in other words, could quite easily consume several years' worth of remittances, and demonstrating that one has at least partially met the costs of that wedding oneself has come to be an important way for young men in the village to establish their capacity to provide.

It was to find the money to marry that Ashym, Jengish's elder brother, had initially traveled to Russia in 2002, and when I first met him, shortly

40. On the social significance of weddings and circumcision ceremonies as enactments of community membership and as sites for ritual gifting, see Sergei Abashin, "Vopreki 'zdravomu smyslu'? (K voprosu o 'ratsional'nosti/irratsional'nosti' ritual'nykh raskhodov v srednei Azii," in Sergei Panarin, ed., Evraziia: Liudi i mify (Moscow, 2003), 217-38 on Uzbekistan; Sophie Roche and Sophie Hohmann, "Wedding Rituals and the Struggle over National Identities," Central Asian Survey 30, no. 1 (March 2011): 113-28 on Tajikistan; and Cynthia Werner, "Household Networks, Ritual Exchange and Economic Change in Rural Kazakhstan” (PhD diss., Indiana University, 1997), 238-69 on Kazakhstan. 
after he had had the nike, the religious ceremony of marriage, he was busy making plans for the wedding feast, the toi, that would formally mark his marriage in the eyes of the village. By 2008, Jengish, now back in Batken having finished his last year of university, was also preoccupied with marriage. For he, too, was of an age to wed, and he was reluctant to have to rely entirely on his brother's earnings to fund the wedding feast. "When you go to a toi now," he explained to me in the summer of 2008, "people don't just look at what food you are serving. They look at how you've repaired your house, what you have inside, what you've brought back [from Russia]." "And if you don't do a toi?" I asked. "If you don't do a toi, it would be uiat (toi kylbasang uiat bolot-ta)," Jengish replied, invoking a term that speaks at once of embarrassment, shame, and the potential for social censure. Indeed, as several of my interlocutors pointed out, it was precisely the "inflation" in ritual expenses that was keeping young men in Russia for large parts of the year. "They'll suck their cheeks all year in Russia to make sure they can invite everyone, get the best singer at their celebration," one Batken elder put it to me, adding, with a vigorous swing of his arm, "you've got to understand that! When people come back they want to invite everyone, they want everyone to know that they have been away, that now they are back, they can have such a toi. That way [they know] it was worth it."

\section{Green Money: Remittances, Ritual, and Social Presence}

The importance of ritual expenses as a destination for remittances emerges vividly from the survey responses of returned migrants. Respondents from households with one or more migrating member were asked to indicate both the disbursements on which remittances in their household were spent (including everything from everyday living costs up to large singleitem purchases or investment in buildings, land, and livestock), as well as the approximate value for each of these different expenditures, indicated either as a percentage of the total sum of money remitted during the previous twelve months or as a monetary sum. ${ }^{41}$ The amount remitted varied considerably, but a fairly consistent pattern of expenditures nonetheless emerged, with everyday expenses, household repairs, the purchase of livestock; the paying off of debts, the cost of university fees, and the conduct of life-cycle ceremonies the most frequently mentioned destinations.

Table 5 indicates these expenses in tabular form, revealing that around a quarter of all the money being remitted and brought back to the four villages surveyed is being invested in what can be considered immediate consumables: food, fuel, clothes, shoes, and schoolbooks. Of the remaining money circulating in the village, three expenses stand out as particu-

41. The resultant sums were indicated in three different currencies (typically Russian rubles or U.S. dollars, but occasionally also in Kyrgyz som). I have converted all of the figures relating to remittances into rubles and then into their dollar equivalents based on average exchange rates for the twelve months to July 2005 to allow for ease of comparison. 
Table 5

Expenses and Monetary Values of Remittances in Ak-Tatyr and Neighboring Villages, 2004-5 ( $n=129,3$ nonresponses).

\begin{tabular}{|c|c|c|c|}
\hline Expenditure & $\begin{array}{l}\text { Percentage of } \\
\text { times that a given } \\
\text { expense was } \\
\text { mentioned as } \\
\text { one of multiple } \\
\text { possible } \\
\text { expenditures }\end{array}$ & $\begin{array}{l}\text { Average } \\
\text { expenditure on } \\
\text { each particular } \\
\text { outlay in rubles } \\
\text { (based on all the } \\
\text { occasions that a } \\
\text { given expenditure } \\
\text { was mentioned) }\end{array}$ & $\begin{array}{l}\text { Percentage of } \\
\text { the total } \\
\text { amount of } \\
\text { remitted money } \\
\text { circulating in } \\
\text { the village in } \\
2004-5 \text { destined } \\
\text { for a given } \\
\text { expenditure } \\
\text { (total }=100 \% \text { ) }\end{array}$ \\
\hline To cover everyday living costs & 51.2 & $10,207(\$ 364)$ & 25.7 \\
\hline $\begin{array}{l}\text { To carry out household } \\
\text { repairs }\end{array}$ & 31.0 & $11,952(\$ 426)$ & 18.2 \\
\hline To purchase livestock & 24.0 & $5,162(\$ 184)$ & 6.1 \\
\hline To pay off debts & 19.4 & $4,570(\$ 169)$ & 4.4 \\
\hline $\begin{array}{l}\text { To contribute to the } \\
\text { costs of a relative's/ } \\
\text { neighbor's toi }\end{array}$ & 15.5 & $6,572(\$ 234)$ & 4.9 \\
\hline To purchase a car & 10.9 & $37,537(\$ 1,337)$ & 20.0 \\
\hline To pay for university fees & 10.1 & $5,869(\$ 209)$ & 2.9 \\
\hline To pay for my own wedding & 8.5 & $15,864(\$ 565)$ & 6.7 \\
\hline $\begin{array}{l}\text { To contribute to the costs of a } \\
\text { sünöt toi for one's own son }(\mathrm{s})\end{array}$ & 7.9 & $12,298(\$ 438)$ & 4.7 \\
\hline To purchase land & 7.8 & $9,534(\$ 340)$ & 3.6 \\
\hline To start a business & 7.0 & $5,942(\$ 212)$ & 2.0 \\
\hline $\begin{array}{l}\text { To purchase/build a new } \\
\text { house }\end{array}$ & 0.8 & $20,000(\$ 713)$ & 0.8 \\
\hline
\end{tabular}

larly remittance-heavy: the purchase of cars (consuming 20 percent of the total remitted cash in 2005); the carrying out of household repairs (a further 18.2 percent), and the conduct of life-cycle ceremonies (16.3 percent of the total money remitted to the village).

When these figures are explored in light of the qualitative interviews, however, what emerges frequently is the capacity of lineage obligations to "trump" other expenditures, including those that in other circumstances might be considered essential to household survival. Several recently returned migrants explained how the expenses that they had anticipated meeting while working in Russia had been subordinated to the needs of helping relatives with the cost of hosting a toi once they returned home. Others described how the money earned over the course of a year had "gone in a day" upon return to the village. Salkynai-apa, 42 years old, who had returned from her own first season in Russia four months before I first interviewed her in the spring of 2004, explained how the 9,000 rubles 
that she had managed to save from working as a cleaner in Moscow went almost immediately in helping her brother meet the costs of the circumcision feast for his two young sons. She described the expenses entailed as follows:

S: For any toi you are bound to have large expenses. If you are paying in Russian rubles, a single sheep is going to cost you 3,000 rubles (\$110). With Kyrgyz som that's going to be 4,500 som. 4 sheep and that's 18,000 [som] gone $(\$ 450)$.

M: And for the toi as a whole, what kind of costs are involved?

S: If you add together everything 80-90,000 [som] will go toward it (c. $\$ 2,100)$. Are the Kyrgyz going to get rich that way?! Think about it. That's a year's income. [. . .] For instance, take my own younger brother, last year he did a toi in December, a circumcision ceremony for his two sons. We used 3,500 flatbreads (nan). 3 som each. We invited all our relatives. 300 kilograms of rice went [into the feast], 42 kilograms of meat. On top of that, we killed 10 sheep. We have to feast those who come to the toi. For every seven families who come, we have to kill one sheep. Our guests should be eating that day and night after that! The next day there's also a toi. We make 130 bags [of gifts]. We put kattama [a large fried flatbread] and bread into a parcel as a present for the elderly people.

M: You said before that you had worked in Russia and came back in December. Did all the money you earned in Russia go toward the toi? Or did you have some left over?

S: With the money I brought back, I bought all the bread for the toi. Here everyone in the same lineage helps us [bizge tuugan uru jardam beret $]$. I gave all the money for the flatbreads. 3,000 of them.

M: So that was about 9,000 som, is that right?

S: Right, I gave all that! I've got a father and mother. I brought them a dress and a coat [chapan]. I gave presents to other relatives. In that way, every penny that I earned there disappeared!

At this point in the interview, I pressed Salkynai-apa on the nature of the social obligations entailed. Was it possible, I wondered, for somebody to reject these expenses? Striking in Salkynai-apa's response was the contrast between her "official" position ("I can tell you about this as the village head ....") and the imperative to follow the social obligations of custom and tradition ( salt), a Kyrgyz term that I leave untranslated in the following extract:

M: And what if, for instance, someone goes to Moscow and is able to earn some money. He comes back wealthy but says, "I don't want to hold a toi. I really need to buy a car." You said that about 80,000 som goes on a toi-about the same as for a car. What would happen if he bought a car rather than holding a toi?

S: Here doing a toi is salt [bizde toi kylysh bul salt]. I came back from Moscow after 10 months. My younger brother brought back 50,000 som. All of it went toward the toi straight away. 
M: And what if you weren't to have held a toi?

S: You've got to do a toi! If you don't do one, your children would feel inadequate [gönülün jaiyna tüshpöit, lit. their mood will not fall into place]. Imagine going round without having done a toi, it will be shameful [uiat]! [. . . ] Now we are sitting open-mouthed saying ahhhhh [in hunger], waiting for the wind to feed us! Everything we've earned in the year, we've ended up giving away, giving out to the people, holding a toi. We never think about how much tomorrow is going to cost. The Kyrgyz themselves are cleaning themselves out [of money], causing themselves huge problems. At the moment I can tell you about this as the village head [aiyl bashchysy]. We should be reducing our expenses on tois to what they used to be according to our old traditions [kaada salt boiuncha], we should make them run on time [saaty menen baraturgan kylyp]. I mean look, now we have to give a new daughter-in-law 10 mattresses [körpö]. They just lie there, unused! We try to tell people, "don't give more than 6 mattresses. We're telling people, "try to keep your [ritual] expenses modest." But the Kyrgyz will compete with each other, making life hard for each other. [That's why] our children are going to Russia, working in real hardship [kyinalyp ishteit]. Turkish firms, Russian firms. At least the Russian ones allow you to rest. In the Turkish firms there's absolutely no rest at all! Turkish firms have never heard of holidays! We celebrate 1 May, 9 May, they are holidays for us. But in the Turkish firms they don't recognize those at all!

Salkynai-apa's narrative provides a poignant insight into several of the issues at stake. "Excessive" ritual expenditure emerges from her narrative as at once a source of frustration and a fact of life. Young people from the village work in Russia "in real hardship" because of social pressures and the demands of showing respect. And there is real ambivalence about the possibility of changing this situation, signaled in the slippage between the "I" of the village head, seeking to intervene and change patterns of behavior, and the "I" who has compelling social obligations as a sister and fellow villager; the "I" who spent 9,000 som on loaves of bread for a nephew's circumcision feast. Salkynai-apa's response to my question concerning the possibility of doing things differently- "here doing a toi is salt"-is at once a statement of fact and an index of obligation, one that obviates the need for further explanation because it carries the force of law. Indeed, salt is sometimes translated as "customary law"-a term that signals both its experiential force and the role of social sanction and censure in ensuring conformity. ${ }^{42}$

The tension that Salkynai-apa alluded to here, seemed, if anything, to have intensified in the five years since I first interviewed her. Between 2005 and 2010, the cost of bride-price in Ak-Tatyr had risen from 40,000 to 60,000 som - an increase my informants attributed to the rising costs of the clothes, food, and fabric that the bride-price would be used to buy. When I returned to Jengish's home in Ak-Sai in early 2010, the village's

42. Beyer, "According to Salt," 33-36. 
women's committee (aialdyn komiteti) was actively debating this increase and the role of women in trying to halt it. On a snowy February afternoon, a group of eleven women convened a special meeting to discuss methods for curtailing the costs of ritual expenditure, and particularly the conduct of weddings by the "boys back from Russia" ( rossiiadan kelgen baldar). One participant criticized another for allowing her son to include eleven Mercedes cars in his wedding cortege to "show off" to his friends. Another harangued the feisty committee chair, Baktygul-eje, for hypocrisy: while she, with married sons, could easily tell them to cut their expenses, if it were her son who were marrying, she would have supported him in celebrating his success.

Such debates are diagnostic, I suggest, of a moment of tension between a ritual economy oriented toward collective participation and obligation - and thus, toward social leveling — and the considerable variation in domestic economies dependent overwhelmingly now on remittances from Russia. In Ak-Sai, where everyone in the village is incorporated into chains of reciprocity to everyone else, it is usual to invite the whole village to at least part of a three-day toi. As Jengish and many other interlocutors pointed out, not to go to the wedding of a neighbor or lineage member is uiat - it invites social sanction and social commentarywith the result that young people are leaving the village now precisely to be able to sustain meaningful participation in village life.

The other side of this, however, is that hosting a toi at which the whole village is invited is the central social mechanism through which one pays respect to parents and elders and affirms one's social membership. A sünnöt-toi, for instance, while celebrated to mark the circumcision of a son or sons, is ultimately conducted and spoken of as being "for the people" (el üchün). Sergei Abashin has noted how in rural Uzbekistan the idiom through which full male adult membership in the village is expressed is that of hosting others, literally, "laying the tablecloth in front of the people." ${ }^{43}$ In Ak-Tatyr the idiom usually invoked is that of dignity (namys) or respect (urmat). Holding a toi is a way of affirming dignity, but it also demands personal sacrifice: namys, in the words of an often-invoked Kyrgyz proverb, is "harder than death" (namys ölümdön kattuu).

It is in this context, I suggest, that we need to attend to the importance of ritual expenditure, not as a "frivolous" waste of money, but as an active investment in the cultivation of social relations that are as material and present as the repairs to homes and the secondhand Audi cars that now sit in the courtyards of many Ak-Tatyr homes. When my elderly informant commented that only by conducting a toi in which everyone is invited could a returned migrant know that his labor abroad "was worth it," this was not simply a rhetorical flair. Many of the young men I interviewed pointed to the importance of investing remittances in ritual celebrations to which friends, neighbors, and lineage members were invited precisely as a way of affirming that they were still here: in the gifts and

43. Abashin, "Vopreki 'zdravomu smyslu'?” 223. 
blessings they distributed, in the sons whom they had circumcised or the daughters whom they had "given away" in marriage, in the merit they generated as words about their deeds circulated, and in the debts accrued to them.

To note this is not to romanticize such expenditure as the manifestation of an essential and unchanging Kyrgyz culture. Nor is it to imply that such obligations do not generate crippling debts - ones that place intense pressure on those thus indebted to seek work in Russia themselves. After all, the recognition that ritual practices are "changing" as a result of green money circulating unevenly in the village figured passionately in everyday conversation, just as it was the object of more formal meetings like the one organized by the Ak-Sai women's committee. It is to stress, rather, the importance of asking what such expenditures mean and what they $d o$ in a context where previous possibilities for gendered social affirmation through paid employment, trade, or military service are constrained.

Practices of ritual gifting, as Abashin notes in his study of life-cycle feasts in Uzbekistan, are historically rooted and suffused with religious and social significance: vehicles, potentially, for the distribution of wealth and the accumulation of merit. ${ }^{44}$ They play a crucial role in marking gendered membership in a lineage and village community and in materializing social presence. Yet they also serve to enact and reproduce social interdependence, the importance of which is heightened precisely in contexts where other forms of social provision are in radical retreat. Cynthia Werner, studying the enormous investment of Kazakh villagers in household networks at a time of acute economic hardship, shows how gifting helps to substantiate relationships that are essential for getting by: a dynamic she characterizes as the "security of mutual indebtedness." ${ }^{55}$ In rural Kyrgyzstan, the radically deregulated labor market sector in which so many village men now participate has, if anything, heightened the importance of such relationships: securing work and accommodation in Russia depends crucially on having friends and acquaintances to help; networks, as we have seen, that are overwhelmingly village based. Far from an "irrational" investment then, ritual expenditure may prove a crucial mechanism for navigating the shocks of the neoliberal economy.

\section{Postsocialist Futures}

In rural Kyrgyzstan, new forms of economic practice and the retreat of state provisioning have served, if anything, to give new significance to the household as a domain of collective production and consumption. Moreover, my research suggests that new forms of engagement in distant labor markets have also been used to sustain — and indeed, invigorate - forms of ritual exchange that are identified locally as manifestations of "tradi-

44. Ibid., 217-38.

45. Cynthia Werner, "Household Networks and the Security of Mutual Indebtedness in Rural Kazakhstan," Central Asian Survey 17, no. 4 (1998): 597-612. 
tion" located outside the realm of individual accumulation. For many of my informants, this distinction was articulated through the way in which, in different social spaces, the money of labor mattered: if in Russia, "it costs you even to breathe," as one of my informants put it, in the village, social respect demands the performance, at least, of magnanimity - even if, as Salkynai-apa demonstrated, ritual expenditure is minutely calibrated behind the scenes.

This has implications for studies of migration from Central Asia, which have tended to pay little attention to the social embeddedness of the economy. It also suggests that we should be cautious about extrapolating too readily from the remaking of economic systems to the remaking of selves. In the postsocialist context there has emerged a rich strand of research concerned with examining the penetration of neoliberal rationalities into everyday life, such as the institutionalization of calculative technologies into formerly socialist production sites, the privatization of labor and leisure, and the role of imported technologies and discourses in interpolating the consuming subject as a singular "you," shaping formerly socialist subjects into what Alexei Yurchak has characterized as a "neoliberal "homo economicus." 46 Such studies have made important contributions to our understanding of how particular, culturally situated economic logics come to travel. Yet in our search for understanding what is newand perhaps, too, in our desire for conceptual coherence - there is a risk of an overly determinist reading of the potential for new rationalities of calculative choice to remake persons and conceptions of self.

Part of this risk, I believe, is borne of linguistic currency. "Neoliberalism" as a descriptor for a planetary state of being has become so dominant an aspect of context (the "neoliberal world order" of much contemporary theory) that it has tended to occlude empirical attention to how, in its diverse instantiations, neoliberal policies unfold, or how certain economic rationalities do (or do not) come to alter conceptions of the self. As Lisa Rofel notes in her study of contemporary China, the term has rapidly come to imply both "a uniformity to experiences of capitalism throughout the world" and to suggest "a monolithic emergence of novel subjectivities." 47 But if part of the challenge is born of language, part of the challenge is also conceptual and methodological: it is easier to chart and measure a shift in discourse, the introduction of new logics of commercial production, or the spread of particular ideological codes than to explore the ambiguous and often contradictory way in which individual people

46. Alexei Yurchak, "Russian Neoliberal: The Entrepreneurial Ethic and the Spirit of "True Careerism,"” Russian Review 62, no. 1 (January 2003): 73. On the "remaking of labor" in a postsocialist factory, see Elizabeth Dunn, Privatizing Poland: Baby Food, Big Business and the Remaking of Labor (Ithaca, 2004); on the role of advertising discourse in individuating subjects, see Aleksei Iurchak, "Po sledam zhenskogo obraza: Simvolicheskaia rabota novogo reklamnogo diskursa," in Anna Al'chuk, ed., Zhenshchina i vizual'nye znaki (Moscow, 2000).

47. Rofel, Desiring China, 19. 
navigate these shifts, by turns appropriating and rejecting the ideologies they encounter.

The value of an ethnographic perspective lies precisely in attending to such complexity. Materials from Ak-Tatyr suggest that the relationship between economic restructuring and individual subject formation is far from linear or straightforward. Logics of neoliberal accumulation, premised upon the rational, autonomous individual engaging in market-type choices, are "domesticated," to borrow Adrian Smith and Alena Rochovská's evocative idiom, in unexpected and counterintuitive ways. ${ }^{48}$ In the Batken region, as throughout Central Asia, calls to "rationalize" expenses on lavish life-cycle ceremonies, for instance, are common in popular discourse, just as they have come to circulate in policy documents and presidential speeches. But calls to live "modestly," to conduct ceremonies "by the clock," to invest remittances in education or businesses rather than on life-cycle ceremonies, or to reduce the bride-price or the size of a young woman's dowry are, as we have seen with Salkynai-apa's commentary on the force of salt, often undermined by social pressures that demand that those who have had a successful season "in town" invest their money in affirming social presence at home.

This finding points, in turn, to a further conclusion concerning our analytical tools. Explanations of change in terms of "postsocialist transition" have been (quite fairly) subject to critique within the social sciences as teleological, restrictive, and perhaps just plain out-of-date. ${ }^{49}$ But in critiquing the normative baggage with which the term has become burdened, we should be wary of abandoning the value of a postsocialist analytic for thinking about lives lived translocally in the former Soviet space. In villages such as Ak-Tatyr, the experience of labor, and its moral assessment, are inflected by understandings of work, rest, hierarchy, and collectivity that are shaped by multiple pasts, including three generations of Soviet socialism. When Salkynai-apa condemns the Turkish construction companies for ignoring Labor Day and Victory Day-days that ought, "properly," to be ones of rest and celebration; when villagers organize themselves into a "brigade" to be hired collectively on a private, domestic building site; or when "Gorkii," today's Nizhnii Novgorod, is spoken of, half-jokingly, as a "Kyrgyz town," these are comments that speak from a sense of "right-ordering" that is historically and culturally situated. This is not to deny that such conceptions are being radically challenged by the fact of work that is invisible to stately systems of accounting, profoundly exploitative, and intensely precarious. It is rather that we can only grasp the pathos of such changes by exploring the historically grounded senses

48. Adrian Smith and Alena Rochovská, "Domesticating Neo-Liberalism: Everyday Lives and the Geographies of Post-Socialist Transformations," Geoforum 38, no. 6 (November 2007): $1163-78$.

49. Michael Burawoy and Katherine Verdery, eds., Uncertain Transition: Ethnographies of Change in the Postsocialist World (Lanham, Md., 1999); Morgan Liu, "Detours from Utopia on the Silk Road: Ethical Dilemmas of Neoliberal Triumphalism," Central Eurasian Studies Review 2, no. 2 (Spring 2003): 2-10; Keough, "Globalizing 'Postsocialism."” 
of selfhood, labor, and political belonging that such processes come to disrupt. Attending to what socialism meant and continued to mean for diverse groups of people (including for that growing generation who never lived under communist rule) is crucial for understanding both the dynamics of contemporary labor migration within the former Soviet space and the emotion that attaches to becoming "guest workers" in sites of continued affective attachment. 